\title{
REDUCING SUGARS IN THE URINE AND BLOOD OF PREMATURE BABIES
}

BY

\author{
J. C. HAWORTH and MORAG S. MACDONALD \\ From the Jessop Hospital for Women, Sheffield, and the Children's Hospital, Sheffield
}

(RECEIVED FOR PUBLICATION JUNE 11, 1957)

We reported previously the finding by paper chromatography of reducing sugars in the urines of 24 out of 50 normal full-term babies (Haworth and McCredie, 1956). We suggested that the galactose which we found in the urines of 13 of the 50 babies might be related to the functional inefficiency of the liver that is so commonly a feature of the newborn. If this were so it might be expected that premature babies, in whom the liver is less efficient functionally than in full-term babies, and in whom 'physiological' jaundice is therefore more frequent and more marked, would excrete reducing sugars to a greater degree than babies born at full term. We therefore examined the urines of 26 male premature babies by paper chromatography and the blood of 10 of them after feeds. This paper is the report of our findings.

\section{Method}

Urines were examined from an unselected group of 26 male premature babies. Twenty-two of them were born at the Jessop Hospital for Women, Sheffield, two were born at home and admitted to the same hospital on the first day of life and two others were born at home and admitted to the Children's Hospital, Sheffield, on the second and third days of life respectively.

The birth weights of the babies varied from $2 \mathrm{lb} .15 \mathrm{oz}$. to $5 \mathrm{lb} .5 \mathrm{oz}$. and their estimated gestation varied from 32 to 40 weeks.

It was planned to collect urines from each baby on the first day of life and thereafter on alternate days until the baby was discharged from hospital, that is, when its weight approached $5 \frac{1}{2} \mathrm{lb}$. This did not prove possible in every case, although in most cases the first urine was examined before the baby had received a feed. In three cases urine collection had to be abandoned or interrupted because of skin irritation or soreness caused by the adhesive strapping used to hold the collecting tubes in position.

All babies were fed with breast milk. In the case of the smaller babies the feeding was not started until the second or third day of life and most were given a few feeds of glucose water before the breast milk was offered. In most cases it was not possible to correlate the times of feeding with the times of micturition.
The degree of clinical jaundice of the first 14 babies was recorded each day by the same observer under similar conditions of light and serum bilirubin was estimated only if deep jaundice was present. In Cases 15-26, however, routine estimations of the serum bilirubin were made, usually on the third, fifth and seventh days of life.

The chromatographic technique employed for the urines was similar to that described in our previous report, except that the triangular-shaped filter papers were bisected after removal from the solvent. By this means different developers could be sprayed on to the two halves if required as described by Horrocks and Manning (1949).

Blood was obtained from heel pricks, about $\frac{1}{2} \mathrm{ml}$. being taken into small dry tubes. Enough $20 \%$ trichloracetic acid was then added to precipitate all the protein (usually about five drops) and after centrifuging $50 \mu \mathrm{l}$. of the supernatant fluid was applied direct to the filter paper. The procedure then was identical with that employed for the urines.

\section{Results}

Urines. One hundred and fifty-two urines from 26 babies were examined and the results are shown in Tables 1 and 2.

TABLE 1

NUMBER OF PREMATURE BABIES AND URINES IN WHICH REDUCING SUGARS WERE FOUND

\begin{tabular}{|c|c|c|c|}
\hline Reducing & Sugar & $\begin{array}{c}\text { No of Babies } \\
\text { Excreting Sugar } \\
\text { on One or More } \\
\text { Occasions }\end{array}$ & $\begin{array}{l}\text { No of Urines } \\
\text { Containing } \\
\text { Sugars }\end{array}$ \\
\hline $\begin{array}{l}\text { Glucose } \\
\text { Galactose } \\
\text { Lactose } \\
\text { Xylose }\end{array}$ & $\begin{array}{l}\ddot{*} \\
\ddot{*} \\
\ddot{*}\end{array}$ & $\begin{array}{r}10 \\
17 \\
17 \\
6\end{array}$ & $\begin{array}{r}22 \\
62 \\
37 \\
8\end{array}$ \\
\hline
\end{tabular}

Twenty babies excreted glucose, galactose, lactose or xylose, or combinations of these sugars, on one or more occasions.

Four babies did not excrete any sugar on any occasion; two babies excreted only an unidentified reducing substance.

Seventy-seven, or $51 \%$, of the 152 urines examined contained one or more reducing sugars.

Three of the babies died with atelectasis when they were 1,3 and 4 days old respectively. Urine from 


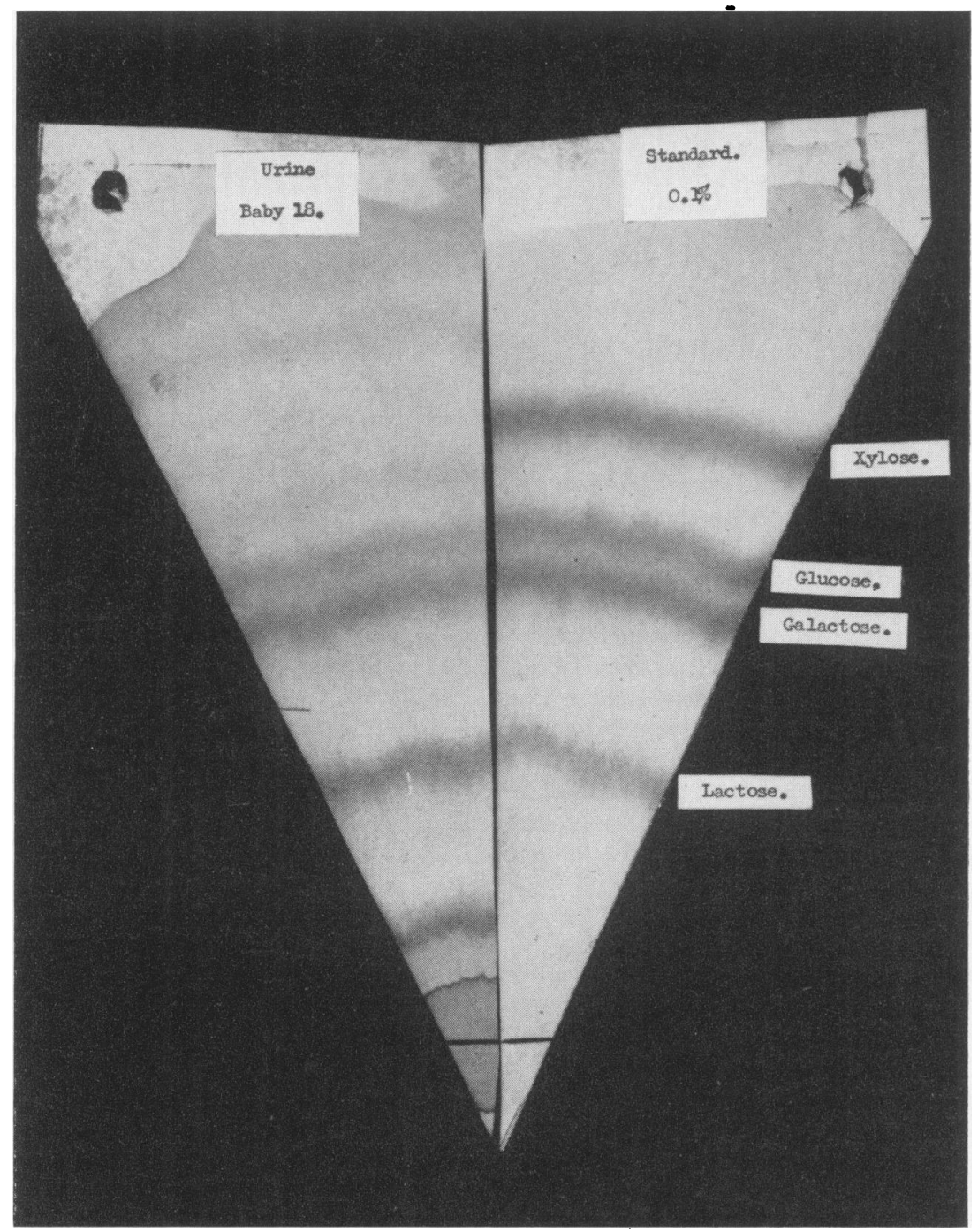

Fig. 1.

TABLE 2

AGES OF 26 PREMATURE BABIES WHEN URINES EXAMINED

\begin{tabular}{|c|c|c|c|c|c|c|c|c|c|c|c|c|}
\hline & \multicolumn{11}{|c|}{ Age in Days of Babies Examined } & \multirow[t]{2}{*}{ Totals* } \\
\hline & 1 & 2 & 3 & 4 & 5 & 6 & 7 & $8-14$ & $15-21$ & $22-28$ & $<28$ & \\
\hline 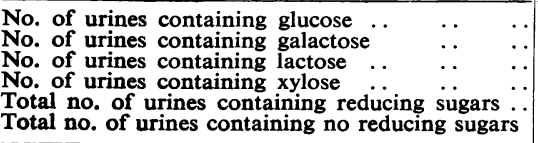 & 7 & $\begin{array}{l}2 \\
1 \\
2 \\
3 \\
5 \\
7\end{array}$ & $\begin{array}{l}5 \\
2 \\
2 \\
3 \\
8 \\
5\end{array}$ & $\begin{array}{l}3 \\
7 \\
1 \\
7 \\
3\end{array}$ & $\begin{array}{l}2 \\
6 \\
5 \\
1 \\
7 \\
5\end{array}$ & $\begin{array}{l}1 \\
6 \\
3\end{array}$ & $\begin{array}{l}3 \\
7 \\
5 \\
7 \\
5\end{array}$ & $\begin{array}{r}14 \\
5 \\
14 \\
20\end{array}$ & $\begin{array}{r}6 \\
10 \\
4 \\
10 \\
8\end{array}$ & $\begin{array}{l}2 \\
5 \\
2 \\
5 \\
7\end{array}$ & $\begin{array}{l}1 \\
9 \\
2 \\
9 \\
5\end{array}$ & $\begin{array}{r}22 \\
62 \\
37 \\
8 \\
77 \\
75\end{array}$ \\
\hline Total no. of urines examined & 7 & 12 & 13 & 10 & 12 & 8 & 12 & 34 & 18 & 12 & 14 & 152 \\
\hline
\end{tabular}

* Many of the urines contained more than one sugar and therefore the totals of urines containing each sugar do not represent the total number of urines examined 


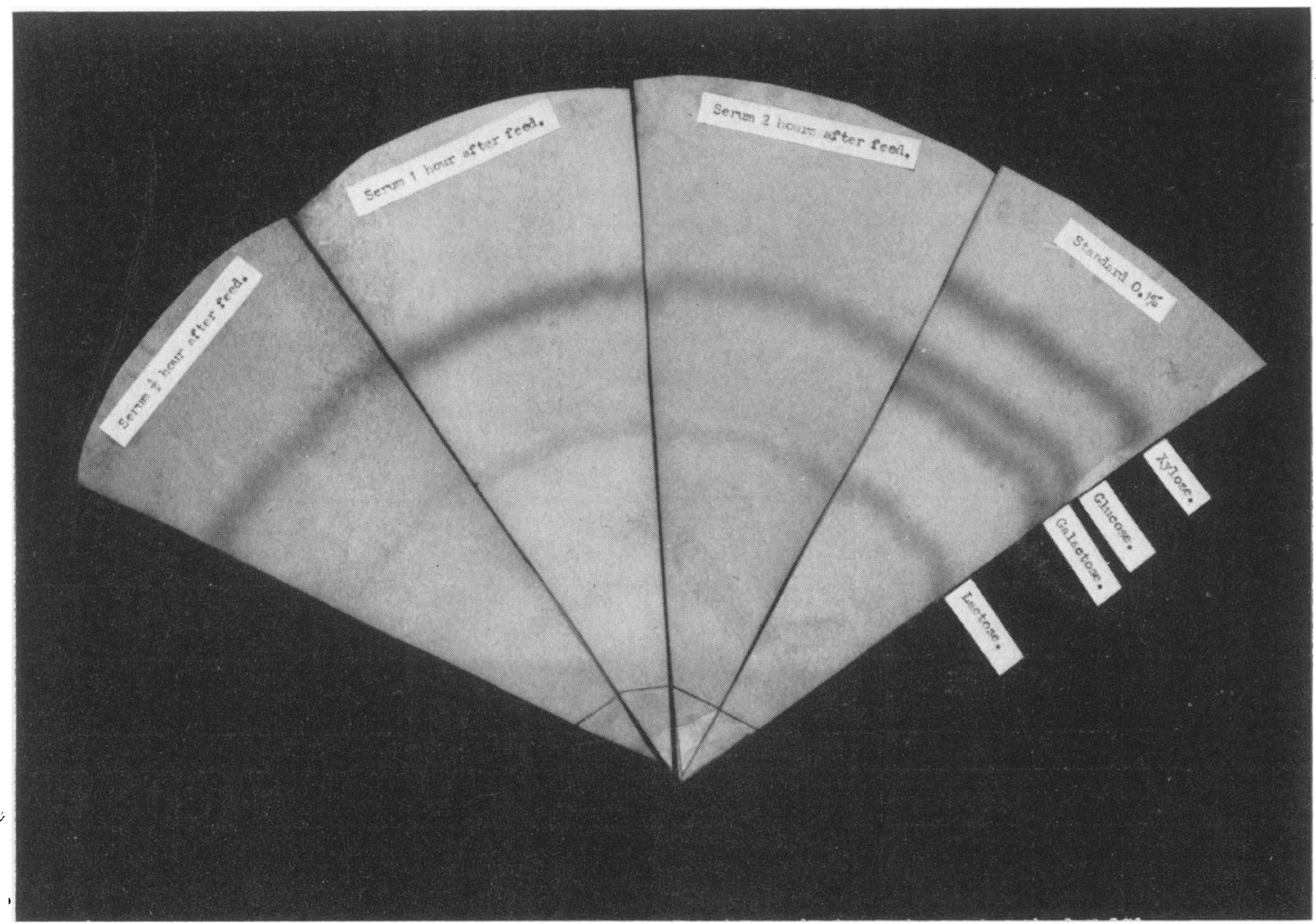

FIG. 2.

one of these babies was collected before the first feed and it did not contain any reducing sugar; urine from another, collected after it had received one ' breast feed, contained glucose and xylose. From the third, two specimens were collected, the first of them, passed before a feed, contained xylose and the other, passed after a feed, contained lactose.

Four of the babies developed hyperbilirubinaemia (not due to blood incompatibility) and exchange transfusions were performed when the serum bilirubin figures reached $20 \mathrm{mg}$. $/ 100 \mathrm{ml}$. One baby had two exchange transfusions. Of these four babies, one excreted sugars in two out of three urines collected, another in 12 out of 16 , the third in six out of 11 and the fourth in one out of two. These babies eventually made complete recoveries.

One baby developed minor umbilical sepsis and another showed signs of cerebral irritability, but these also eventually made good progress. The remaining 17 babies were healthy.

Urines were collected from 15 of the babies before they had received a feed. Of these urines, 11 contained no reducing substance, two contained an unidentified reducing substance, one contained xylose and another glucose.

Most of the babies excreted less than $100 \mathrm{mg}$./ $100 \mathrm{ml}$. of sugar but it was estimated that one baby excreted between 100 and $200 \mathrm{mg}$. $/ 100 \mathrm{ml}$. of galactose on the 30th day of life and four babies excreted the same amount of lactose on one occasion each. Fig. 1 shows the chromatogram of the urine collected from Case 18 on the fifth day of life. Lactose in a concentration of more than $100 \mathrm{mg}$./ $100 \mathrm{ml}$. is shown together with glucose and galactose in smaller amounts. No correlation was found between the number and type of sugars excreted and the degree of jaundice or the serum bilirubin levels of the babies. Neither was there any correlation between the sugars excreted and the degree of prematurity as assessed by birth weight or length of gestation.

Blood. From 10 babies specimens of capillary blood taken after milk feeds were chromotographed and the results are shown in Table 3 . It will be seen that in two instances sugars other than glucose 
were found. Galactose was found with glucose on the 15th day of life in Case 15, but unfortunately it is not recorded how long after a feed this specimen was passed. Lactose was found with glucose half, one and two hours after a feed on the 13th day of life in Case 20 (Fig. 2). From babies 20, 21 and 23, urines were collected while blood samples were being taken and the results are shown in the last column of Table 3. A and B were two female babies from whom urines were not collected. No reducing sugar was found in blood taken two hours after a feed in Case 23, but this may have been because the specimen was too much diluted by an excess of trichloracetic acid.

\section{Discussion}

As shown above, 20 of 26 premature babies excreted reducing sugars in the urine, on one or more occasion, during the first few days or weeks of life. Of 152 urines examined from the 26 babies, $77(51 \%)$ contained one or more sugars. Galactose and lactose were the sugars most commonly found and their source was almost certainly the gut. Neither of these sugars was found in the urine of any baby before a milk feed had been given.

Although there was no correlation between the birth weights of the babies and the sugars excreted, the numbers in the lower birth weight ranges were small and if a larger group had been examined some

TABLE 3

RESULTS OF BLOOD CHROMATOGRAPHY

\begin{tabular}{|c|c|c|c|c|c|c|c|c|}
\hline Case & $\underset{\text { (lb. }}{\mathbf{W e}}$ & $\begin{array}{l}\text { th } \\
\text { ght } \\
\text { oz.) }\end{array}$ & $\begin{array}{l}\text { Age } \\
\text { in } \\
\text { Days }\end{array}$ & $\begin{array}{l}\text { Time } \\
\text { after } \\
\text { Feed }\end{array}$ & Feed & $\begin{array}{l}\text { Approximate } \\
\text { Lactose Content } \\
\text { (g.) }\end{array}$ & $\begin{array}{l}\text { Reducing } \\
\text { Sugars }\end{array}$ & $\begin{array}{l}\text { Urines passed } \\
\text { in Relation } \\
\text { to Feeds }\end{array}$ \\
\hline 15 & 3 & 10 & $\begin{array}{l}15 \\
20\end{array}$ & $\begin{array}{c}\text { Unspecified } \\
\qquad,\end{array}$ & $\begin{array}{l}1 \frac{1}{2} \text { oz. breast milk } \\
1 \frac{1}{2} \text { oz. breast milk }\end{array}$ & $\begin{array}{l}3 \cdot 3 \\
3 \cdot 3\end{array}$ & $\begin{array}{l}\text { Glucose and } \\
\text { galactose } \\
\text { Glucose }\end{array}$ & \\
\hline 16 & 5 & 10 & $\begin{array}{l}4 \\
9\end{array}$ & $\begin{array}{l}1 \text { hour } \\
1 \text { hour }\end{array}$ & $\left.\begin{array}{l}2 \text { oz. } \frac{1}{2} \text { cream Nat. dried milk } \\
3 \text { oz. } \frac{1}{2} \text { cream Nat. dried milk }\end{array}\right\}$ & $\begin{array}{l}\text { Formula } \\
\text { of feed } \\
\text { not recorded }\end{array}$ & $\begin{array}{l}\text { Glucose } \\
\text { Glucose }\end{array}$ & \\
\hline 17 & 5 & 2 & 9 & 1 hour & Breast fed and not test weighed & Not known & Glucose & \\
\hline 18 & 5 & 3 & $\begin{array}{l}4 \\
9\end{array}$ & $\begin{array}{l}1 \text { hour } \\
1 \text { hour }\end{array}$ & $\begin{array}{l}\frac{1}{2} \text { oz. half-strength breast milk } \\
1 \text { oz. breast milk }\end{array}$ & $\begin{array}{l}0 \cdot 6 \\
2 \cdot 2\end{array}$ & $\begin{array}{l}\text { Glucose } \\
\text { Glucose }\end{array}$ & \\
\hline 19 & 4 & 13 & $\begin{array}{l}10 \\
12\end{array}$ & $\begin{array}{l}1 \text { hr. } 10 \mathrm{~min} . \\
\text { half-hour } \\
1 \text { hour } \\
2 \text { hours }\end{array}$ & $\begin{array}{l}1 \text { oz. breast milk } \\
1 \frac{1}{2} \mathrm{oz} \text {. breast milk }\end{array}$ & $\begin{array}{l}2 \cdot 2 \\
3 \cdot 3\end{array}$ & $\begin{array}{l}\text { Glucose } \\
\text { Glucose } \\
\text { Glucose } \\
\text { Glucose }\end{array}$ & \\
\hline 20 & 4 & 8 & $\begin{array}{r}6 \\
13 \\
\\
\\
20\end{array}$ & $\begin{array}{l}1 \text { hour } \\
\text { half-hour } \\
1 \text { hour } \\
2 \text { hours } \\
\text { Before } \\
\text { half-hour } \\
1 \text { hour } \\
2 \text { hours }\end{array}$ & $\begin{array}{l}3 \text { dr. breast milk } \\
11 \text { oz. breast milk } \\
1 \text { oz. breast milk }\end{array}$ & $\begin{array}{l}0 \cdot 9 \\
2 \cdot 75\end{array}$ & $\begin{array}{l}\text { Glucose } \\
\text { Glucose and } \\
\text { lactose } \\
\text { Glucose and } \\
\text { lactose } \\
\text { Glucose and } \\
\text { lactose } \\
\text { Glucose } \\
\text { Glucose } \\
\text { Glucose } \\
\text { Glucose }\end{array}$ & $\begin{array}{l}\text { 1-2 hours after- } \\
\text { feed-glucose }\end{array}$ \\
\hline 21 & 4 & 12 & 8 & $\begin{array}{l}\text { half-hour } \\
1 \text { hour } \\
2 \text { hours } \\
\text { Before } \\
\text { half-hour } \\
1 \text { hour } \\
2 \text { hours }\end{array}$ & $\begin{array}{l}1 \text { oz. breast milk } \\
1 \frac{1}{2} \text { oz. breast milk }\end{array}$ & $2 \cdot 2$ & $\begin{array}{l}\text { Glucose } \\
\text { Glucose } \\
\text { Glucose } \\
\text { Glucose } \\
\text { Glucose } \\
\text { Glucose } \\
\text { Glucose }\end{array}$ & $\begin{array}{l}2 \text { hours after } \\
\text { feed-galactose } \\
\text { 1-2 hours after } \\
\text { feed galactose } \\
\text { and lactose }\end{array}$ \\
\hline 23 & 5 & 3 & 6 & $\begin{array}{l}\text { Before } \\
\text { half-hour } \\
1 \text { hour } \\
2 \text { hours }\end{array}$ & $1 \frac{\mathrm{oz}}{\mathrm{a}}$ breast milk & $2 \cdot 75$ & $\begin{array}{l}\text { Glucose } \\
\text { Glucose } \\
\text { Glucose } \\
\text { Nil }\end{array}$ & $\begin{array}{l}\text { hour after feed } \\
\text { galactose and } \\
\text { lactose }\end{array}$ \\
\hline $\mathbf{A}$ & 3 & 12 & 7 & $\begin{array}{l}\text { Before } \\
\text { half-hour } \\
1 \text { hour } \\
2 \text { hours }\end{array}$ & 2 dr. breast milk & 0.6 & $\begin{array}{l}\text { Glucose } \\
\text { Glucose } \\
\text { Glucose } \\
\text { Glucose }\end{array}$ & \\
\hline B & 5 & 5 & 2 & $\begin{array}{l}\text { Before } \\
\text { half-hour } \\
1 \text { hour } \\
2 \text { hours }\end{array}$ & 1 oz. breast milk & $2 \cdot 2$ & $\begin{array}{l}\text { Glucose } \\
\text { Glucose } \\
\text { Glucose } \\
\text { Glucose }\end{array}$ & \\
\hline
\end{tabular}


correlation might have been found. The figures for sugar excretion in the whole group of premature babies, however, may be compared with those of a group of 50 full-term babies, of whom $24(48 \%)$ excreted sugars in $25(31 \%)$ of 81 urines examined (Haworth and McCredie, 1956). The higher proportion of sugars excreted by the premature babies is statistically significant and it would therefore seem that they are unable to metabolize galactose and lactose as well as full-term babies.

If galactose is excreted in the urine because a functionally inefficient liver is unable to metabolize it fully after absorption, it might be expected that those babies who became more jaundiced would excrete galactose more often than babies who did not show jaundice. In fact no such association between jaundice and galactose excretion was found, and even the four babies whose serum bilirubin levels rose to more than $20 \mathrm{mg}$. $/ 100 \mathrm{ml}$., and were therefore given exchange transfusions, did not excrete galactose to a higher degree than several babies who never became jaundiced or whose highest bilirubin level was below $5 \mathrm{mg} . / 100 \mathrm{ml}$. The giving of exchange transfusions may, however, have influenced the excretion of sugars, but we have no information about this. As Table 2 shows, galactose was often found in urines of babies who were over 28 days old when jaundice had long since faded and when liver function had presumably become normal. This may be compared with the observation that in the group of full-term babies, already referred to, galactose was excreted on the sixth and seventh days of life less often than on the third, fourth and fifth.

Another possible cause for the galactosuria is that the ductus venosus may remain patent for a time after birth, thus allowing some portal blood carrying galactose to bye-pass the liver and to empty directly into the systemic circulation. van Creveld (1929) thought that this might be a possible cause for the hypoglycaemia found in premature babies in the neonatal period, although he thought functional immaturity of the liver was a more likely cause. It is known that the ductus venosus may remain patent anatomically for as long as two months after birth (Scammon, 1923), but there is no evidence that it remains functionally patent after birth. Lind's (1953) observations in full-term babies suggest that it does not.

The lactosuria found in 17 of the babies ( 37 urines) and the lactose found in the blood of Case 20 after a milk feed indicate that not all the lactose is hydrolysed in the gut but that a proportion of it is absorbed unsplit and is excreted because it cannot be metabolized. It can only be assumed that this is due to inadequacy of lactase. Lactose was found in urines of babies as old as 4 weeks, but the figures in Table 2, although small, do suggest that a higher proportion of urines containing lactase was collected from babies aged 4-7 days. This might indicate an increasing ability of the older babies to hydrolyse lactose. Ibrahim (1910) stated that lactase is the last of the disaccharide-splitting enzymes to appear and is often absent until the eighth foetal month.

It might be considered surprising that galactose and lactose were not found more often in the blood samples taken after feeds, especially when these sugars were found in the urines (Cases 21 and 23) passed during the collection of the blood. It is possible that the concentration of the sugars in the blood was too low on many occasions to be demonstrated by the method used.

Xylose was found in eight urines from six babies, on one occasion before a feed had been given. This feature was not found after the fifth day of life and its source remains obscure.

\section{Summary}

Urines from 26 male premature babies were examined for reducing sugars by paper chromatography. Twenty babies excreted glucose, galactose, lactose and xylose or combinations of these sugars on one or more occasions. Reducing sugars were found in 77 of 152 urines examined.

Sugars were found more frequently in the urines of these premature babies than in a group of fullterm babies.

Blood from 10 premature babies was examined for reducing sugars after milk feeds. In one, galactose was demonstrated and in another, lactose.

Thus premature babies are not able to metabolize galactose and lactose fully and the possible causes of this are discussed.

We are grateful to Dr. T. Colver and Professor R. S. Illingworth for permission to investigate the premature babies under their care and to them and Dr. J. L. Emery for helpful criticism. We also thank Miss E. Finch for giving us laboratory facilities and the sisters at the Jessop Hospital for Women for their help in collecting the urines.

\section{REFERENCES}

Creveld, S. van (1929). Amer. J. Dis. Child., 38, 912.

Haworth, J. C. and McCredie, D. (1956). Archives of Disease in Childhood, 31, 189.

Horrocks, R. H. and Manning, G. B. (1949). Lancet, 1, 1042.

Ibrahim, J. (1910). Hoppe-Seyl. physiol. Chem., 66, 19.

Lind, J. (1953). In Anoxia of the New-born Infant: A Symposium organized by the Council for International Organizations of Medical Sciences, p. 184. Oxford.

Scammon, R. E. (1923). In Pediatrics, edited by Abt, I. A. Vol. 1, p. 388. Philadelphia and London. 